Jurnal Pendidikan Matematika : Judika Education

Volume 2, Nomor 1, Januari-Juni 2019

e-ISSN : 2614-6088

p-ISSN : 2620-732X

DOI: https://doi.org/10.31539/judika.v2i1.624

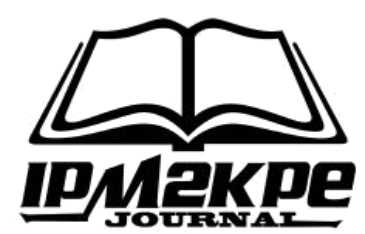

\title{
PENGGUNAAN APLIKASI SOFTWARE GEOMETER'S SKETCHPAD PADA PEMBELAJARAN MATEMATIKA UNTUK PENINGKATAN PEMAHAMAN KONSEP TRANSFORMASI SISWA
}

\author{
Asmawati \\ Guru SMP Negeri 1 Tebat Karai Kabupaten Kepahiang \\ Asmawatis2mat@gmail.com
}

\begin{abstract}
ABSTRAK
Tujuan penelitian, untuk meningkatkan kemampuan memahami konsep transformasi materi melalui implementasi pembelajaran berbasis TIK menggunakan perangkat lunak Sketchpad Geometer pada siswa SMP Tebat Karai 1 Kabupaten Kepahiang. Metode, penelitian ini merupakan penelitian deskriptif komparatif. Sampel adalah Siswa kelas IX berjumlah 30 orang. Analisis data menggunakan analisis komparatif deskriptif. Setelah deskriptif komparatif dilanjutkan reflektif. Hasil penelitian, peningkatan dari kondisi awal nilai rata-rata mahasiswa dari 44,67 menjadi 65,83 pada siklus pertama dan naik menjadi 77,42 pada siklus kedua. Sehingga dari kondisi awal ke siklus pertama, meningkat sebesar 44,37\%, dari kondisi awal ke siklus kedua meningkat sebesar 73,33\% dan diklasifikasikan sebagai kategori tinggi. Hasil pengamatan aktivitas siswa meningkat dalam proses pembelajaran dengan kategori tinggi. Simpulan, penggunaan media berbasis TIK menggunakan Perangkat Lunak Sketchpad Geometer dapat meningkatkan keterampilan pemahaman konseptual siswa dalam transformasi materi, dan dapat meningkatkan aktivitas siswa.
\end{abstract}

Kata Kunci: Perangkat Sketchpad Geometer, Pemahaman Konsep

\begin{abstract}
The research objective is to improve the ability to understand the concept of material transformation through the implementation of ICT-based learning using the Sketchpad Geometer software for Karai 1 Tebat Middle School students in Kepahiang District. Method, this research is a comparative descriptive study. The sample is grade IX students totaling 30 people. Data analysis uses descriptive comparative analysis. After descriptive comparative continued reflective. The results of the study, an increase from the initial conditions the average value of students from 44.67 to 65.83 in the first cycle and rose to 77.42 in the second cycle. So that from the initial conditions to the first cycle, increased by $44.37 \%$, from the initial conditions to the second cycle increased by $73.33 \%$ and classified as high category. The results of observations of student activity increased in the learning process with a high category. Conclusion, the use of ICT-based media using the Sketchpad Geometer Software can improve students' conceptual
\end{abstract}


understanding skills in the transformation of material, and can improve student activities.

Keywords: Geometer`s Sketchpad Software, Concept Understanding

\section{PENDAHULUAN}

Matematika merupakan mata pelajaran yang paling tidak disukai oleh mayoritas siswa, sampai saat ini pelajaran matematika masih dianggap sebagai pelajaran yang amat sulit untuk dipelajari, membosankan, tidak menarik, bahkan penuh misteri sehingga hasil yang diperoleh siswa masih sangat jauh dari yang diharapkan, bahkan bisa menyebabkan trauma akan pembelajaran matematika.

Aktivitas belajar siswa masih rendah, salah satu penyebabnya adalah siswa kurang memahami konsep dasar matematika sehingga mengalami kesulitan dalam memahami konsep berikutnya. Hal ini diantaranya disebabkan masih kurangnya kreativitas guru matematika dalam menyajikan media pembelajaran yang dekat dengan dunia siswa, pembelajaran yang cendrung tradisioanl dan berpusat pada guru (Arsyad, 2002).

Dalam proses pembelajaran matematika disekolah terdapat beberapa permasalahan terkait dengan karakteristik matematika, objeknya yang abstrak, konsep dan prinsipnya berjenjang, prosedur pengerjaannya banyak memanipulasi bentuk-bentuk yang membuat siswa seringkali mengalami kesulitan. Objek tersebut tidak semuanya bisa divisualisasikan dalam tiga dimensi yang bisa diindrakan dengan baik oleh siswa. Hal ini menuntut peraga dan media yang tepat yang mampu membantu siswa memahami konsep yang diajarkan dan mampu mengatasi keberagaman kompetensi yang dimiliki siswa, serta mengatasi keterbatasan yang ada pada guru.

Untuk mengatasi permasalahan diatas, seiring dengan perkembangan teknologi informasi dan komunikasi (TIK), para programmer berupaya merancang software-sofware matematika. Dengan bantuan software-software proses pembelajaran yang cenderung tradisional dan monoton dapat diubah menjadi proses pembelajaran yang interaktif (Lam, T.T., 2007).

Dengan media software aplikasi matematika, siswa diharapkan mampu untuk menemukan konsep-konsep geometri bersama teman sekelompoknya, menyelidiki data-data tampilan media manipulasi virtual, serta akhirnya menemukan sebuah formula baku untuk konsep matematika tertentu. Aplikasi ini juga mampu membantu siswa dalam proses representasi. Selain itu, pembuktian konsep-konsep geometri pun dapat dibuktikan dengan menggunakan sedikit perhitungan dan manipulasi sederhana (Nugraha, 2017).

Fokus penelitian ini adalah untuk mengimplementasikan pembelajaran berbasis TIK menggunakan software geometer's sketchpad dalam upaya peningkatan Pemahaman Konsep Materi 
Transformasi Siswa Kelas IX SMP Negeri 1 Tebat Karai.

Masalah yang diangkat dari penelitian ini adalah apakah penggunaan software geometer's sketchpad dapat meningkatkan kemampuan pemahaman konsep matematika materi transformasi pada siswa kelas IX SMPN 1 Tebat Karai?

Tujuan Penelitian adalah Untuk mengetahui bagaimana cara yang paling tepat untuk meningkatkan kemampuan pemahaman konsep matematika materi transformasi dan untuk mengetahui seberapa besar peningkatan/dampak yang diperoleh dengan menggunakan pendekatan pembelajaran berbasis TIK menggunakan software geometer's

\section{METODE PENELITIAN Subjek Penelitian}

Adapun yang menjadi subjek dalam penelitian ini adalah siswa kelas IX SMPN 1 Tebat Karai Kabupaten Kepahiang Tahun Pelajaran 2018/2019 semester ganjil dengan jumlah siswa sebanyak 30 orang terdiri atas 16 siswa laki-laki dan 14 siswa perempuan.

\section{Teknik dan Alat Pengumpulan Data Teknik Non Tes}

Teknik non tes ini meliputi observasi dan dokumentasi. Observasi digunakan untuk mengukur tingkah laku individu ataupun proses pembelajaran yang berlangsung dengan menggunakan Software Gemoetri Sketchpad. Observasi dilakukan dengan menggunakan lembar observasi yang telah dipersiapkan yang dikembangkan meliputi observasi terhadap kegiatan pelaksanaan pembelajaran, observasi kegiatan siswa.

\section{Teknik Tes}

Teknik tes dilakukan untuk memperoleh data pemahaman konsep matematika oleh siswa setelah melaksanakan proses belajar. Tes yang dilakukan berbentuk uraian.

\section{Analisis Data \\ Analisis Data Kualitatif}

Analisa data kualitatif terdiri dari; Reduksi data, meliputi penyeleksian data melalui deskripsi atau gambaran singkat dan pengelompokan data dilakukan ke dalam kualifikasi yang telah ditentukan, Beberan (display) data. data penelitian yang telah direduksi perlu dibeberkan dalam bentuk narasi, grafik, atau diagram. Pembeberan data yang sistematik dan interaktif akan memudahkan pemahaman terhadap apa yang telah terjadi sehingga memudahkan penarikan kesimpulan atau menentukan tindakan yang akan dilakukan selanjutnya

Tahap selanjutnya yaitu penarikan kesimpulan dilakukan berdasarkan hasil dari semua data yang telah diperoleh. Penarikan kesimpulan tentang peningkatan atau perubahan yang terjadi dilakukan secara bertahap mulai dari kesimpulan sementara yang disimpulkan pada akhir siklus I, pada akhir siklus II dan kesimpulan terakhir pada akhir siklus terakhir.

\section{Analisis Data Kuantitatif}

Hasil analisis ini akan disajikan 
dalam bentuk persentase. Dalam penelitian ini analisis data kuantitatif diperoleh dari analisis data hasil tes siklus I, siklus II dan siklus terakhir yang ditetapkan sebagai berikut ; 1) analisis data hasil observasi pembelajaran. Data yang diperoleh dari lembar observasi pelaksanaan pembelajaran diberi skor. Adapun ketentuan dalam pemberian skors dituangkan dalam tabel 1 berikut:

Tabel 1.

Skor Lembar Observasi Pelaksanaan Pembelajaran

\begin{tabular}{cc}
\hline Kriteria & Skor \\
\hline 3 & Baik \\
2 & Cukup Baik \\
1 & Kurang Baik \\
\hline
\end{tabular}

Skor pelaksanaan pembelajaran adalah jumlah seluruh skors yang diperolehnya sesuai dengan banyaknya amatan yang muncul atau tampak ketika penerapan pembelajaran menggunakan Software Gemoetri Sketchpad berlangsung. Skor tertinggi aktifitas yang diperoleh siswa adalah $10 \times 3=$ 30 dan skors terendahnya adalah $0 \mathrm{x}$ $3=0$. Analisa hasil observasi dilakukan dengan menghitung ratarata skor pengamatan dengan rumus sebagai berikut:

$$
\mathrm{X}=\frac{\begin{array}{c}
\text { Jumlah } \text { Skor } \\
\text { Pencapaian tiap aspek }
\end{array}}{\begin{array}{c}
\text { jml butir amatan } X \text { jml skor } \\
\text { maksimal tiap aspek }
\end{array}} \times 100 \%
$$

Selanjutnya kisaran nilai yang telah diperoleh dikonversi dengan kategori berikut:
Tabel 2.

Pedoman Kualifikasi Hasil Observasi Pelaksanaan Pembelajaran

\begin{tabular}{cl}
\hline Persentase & \multicolumn{1}{c}{ Kategori } \\
\hline $89 \leq \bar{x} \leq 100$ & Sangat tinggi \\
$77 \leq \bar{x} \leq 88$ & Tinggi \\
$66 \leq \bar{x} \leq 76$ & Sedang \\
$34 \leq \bar{x} \leq 65$ & Rendah \\
$0 \leq \bar{x} \leq 33$ & Sangat rendah \\
\hline
\end{tabular}

Tingkat aktifitas siswa secara klasikal diperoleh dengan rumus:

$$
\mathrm{A}=\frac{\sum \Gamma}{\sum \Psi} \times 100 \%
$$

Keterangan:

A = Tingkat Aktifitas Siswa (\%)

$\sum \Gamma=$ Jumlah Siswa yang Mendapat skors masing-masing Kategori $\sum \Psi=$ Jumlah Seluruh Siswa.

2)Analisis Hasil Tes Pemahaman konsep. Hasil pengerjaan tes pada siklus I, siklus II, dianalisa dengan langkah-langkah sebagai berikut ; a) Menghitung persentase pencapaian seluruh siswa untuk setiap aspek pemahaman konsep dengan rumus sebagai berikut : Jumlah Skor

$$
\begin{gathered}
A=\frac{\text { Pencapaian tiap aspek }}{\text { jumlah klp X jumlah skor }} \times 100 \% \\
\text { maksimal tiap aspek }
\end{gathered}
$$

b) menghitung rata-rata persentase pemahaman konsep dengan rumus sebagai berikut:

$$
\begin{aligned}
& \text { Jumlah persentase }
\end{aligned}
$$

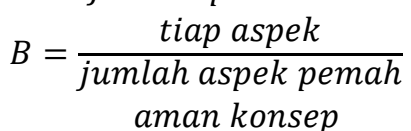

Selanjutnya kisaran nilai yang telah diperoleh dikonversi dengan kategori berikut: 
Tabel 3. Pedoman Kualifikasi Hasil Tes Pemahaman Konsep

\begin{tabular}{cl}
\hline Persentase & \multicolumn{1}{c}{ Kategori } \\
\hline $89 \leq \bar{x} \leq 100$ & Sangat tinggi \\
$77 \leq \bar{x} \leq 88$ & Tinggi \\
$66 \leq \bar{x} \leq 76$ & Sedang \\
$34 \leq \bar{x} \leq 65$ & Rendah \\
$0 \leq \bar{x} \leq 33$ & Sangat rendah \\
\hline
\end{tabular}

\section{Indikator Kinerja}

Indikator keberhasilan dari penelitian ini adalah meningkatnya persentase klasikal rata-rata pemahaman konsep matematika pada materi transformasi dari siklus I ke siklus berikutnya dengan kategori minimal tinggi atau siswa memperoleh nilai minimal 77 serta aktivitas siswa secara klasikal dengan kategori minimal sedang telah mencapai $85 \%$.

\section{Prosedur Penelitian \\ Perencanaan}

Tahap perencanaan dalam penelitian ini meliputi: a) Menyusun silabus; b) Merancang rencana pembelajaran (RPP) yang akan diterapkan dalam proses pembelajaran; c) Mempersiapkan perangkat keras (hardware); LCD, Infokus / bahan-bahan yang diperlukan untuk melaksanakan tindakan; Mempersiapkan media berupa software pembelajar: Software Geometry Sketchpad, PowerPoint; Menyusun lembar kerja siswa (LKPD); d) Menyusun soalsoal untuk tes akhir siklus; e) Menyiapkan Lembar Observasi Aktivitas Siswa.

\section{Tahap pelaksanaan tindakan}

Kegiatan yang dilakukan kami pada tahap ini antara lain: Melaksanakan desain atau penyampaian materi dengan menggunakan media software geometer's sketcphad berdasarkan rencana pembelajaran yang telah dipersiapkanpada tahap perencanaan.

Tahap Pengamatan Terhadap Tindakan

Kegiatan pengamatan dilakukan oleh pengamat (teman kolaborasi) selama proses pembelajaran berlangsung (pada tahap tindakan sekaligus tahap pengamatan), dengan menggunakan lembar observasi yang telah disediakan. Pengamatan bertujuan untuk melihat aktivitas siswa selama proses pembelajaran berlangsung, serta melihat keefektipan daya dukung berupa media software yang digunakan peneliti dalam proses pembelajaran.

\section{Refleksi}

Setelah pengamatan selesai dilakukan berdasarkan observasi dalam rangka memperoleh data, bersama dengan pengamat (mitra kolaborasi) data diolah dan dianalisis, data yang akan dipergunakan sebagai dasar menarik suatu simpulan. Dari simpulan tersebut, kami dapat menentukan perlu tidaknya diadakan penelitian ulang atau penelitian kembali. Bila ternyata hasil simpulan tersebut tidak sesuai dengaan rencana semula yang telah ditetapkan, maka langkah berikutnya mencari faktor-faktor yang menyebabkan adanya ketidaktercapaian tersebut. 


\section{HASIL PENELITIAN \\ Deskripsi Kondisi Awal Aktivitas Pembelajaran}

Pada kondisi awal aktivitas belajar siswa rendah, sebagian besar siswa cenderung pasif dalam mengikuti proses pembelajaran matematika di dalam kelas, siswapun jarang dilibatkan dalam proses pembelajaran, interaksi berlangsung hanya satu arah, siswa lebih banyak sebagai pendengar setia dari pada ikut aktif dalam proses pembelajaran. Hal inilah menjadikan proses pembelajaran matematika yang diikuti tidak bermakna bagi siswa. Mereka cenderung merasa takut dan enggan mengemukakan pendapat maupun pertanyaan.

\section{Hasil belajar}

Hasil belajar pada kondisi awal diperoleh dari hasil ulangan harian Hasil ulangan harian materi "Persamaan dan Fungsi Kuadrat" menunjukkan rata-rata nilai 44,67. Hal ini menunjukkan bahwa hasil belajar pada materi "Persamaan dan Fungsi Kuadrat" masih rendah.

Berdasarkan hasil yang dicapai pada tes awal (pre-test) diketahui bahwa siswa mengalami kesulitan dalam menyelesaikan soal pre-test hal ini terlihat dari tidak ada siswa yang memenuhi indikator dari kemampuan pemahaman konsep. Hal ini menunjukan bahwa kemampuan pemahaman konsep matematis siswa masih rendah. Untuk mengatasi permasalahan ini peneliti melakukan tindakan dalam proses pembelajaran dengan menggunakan pendekatan pembelajaran berbasik TIK dalam hal ini menggunakan bantuan aplikasi software geometer's sketchpad untuk meningkatkan kemampuan pemahaman konsep.

\section{Deskripsi Hasil Siklus I \\ Aktivitas Siswa}

Pada saat proses pembelajaran berlangsung, ketika peneliti mengawali dengan memotivasi, sudah terlihat ada peningkatan aktivitas walau masih ada beberapa siswa yang tidak termotivasi, dalam proses pembelajaran menggunakan software gemoetri sketchpad, secara individu maupun dalam kelompok antusias siswa cukup tinggi meski masih terdapat beberapa orang siswa yang belum mampu berinteraksi dengan sesama kelompoknya, hal ini karena memang siswa belum terbiasa bekerja dengan kelompok yang semua kegiatan dikondisikan dengan baik oleh peneliti, karena dalam mengajar biasanya peneliti memberikan tugas kelompok tidak diberi batasan-batasan, peneliti juga belum memberikan ketentuan berupa tanggung jawab kelompok atau hasil kerja kelompok berpengaruh dari tanggung jawab individu, jika dalam kelompoknya ada individu yang belum terlibat secara aktif maka nilai kelompok akan dikurangi.

\section{Hasil Tes Kemampuan Pemahaman Konsep}

Dari hasil tes siklus I yang telah dilakukan, terdapat 19 siswa dari 30 siswa yang kemampuan pemahaman konsepnya memperoleh kriteria baik, memenuhi KKM $(\geq 70)$. Hal ini jelas masih belum memenuhi dari indikator keberhasilan yang diinginkan.

Hasil belajar siswa mengalami peningkatan dibandingkan dengan kondisi awal. Jika dibandingkan 
dengan kondisi awal nilai rata-rata siswa 44,67 menjadi 65,83 . Nilai tertinggi naik dari 80,0 menjadi 90,0. Nilai terendah 25,0 naik menjadi 32,5. Persentase jumlah siswa yang telah tuntas belajar juga meningkat. Ketuntasan belajar siswa pada siklus I adalah:

Tabel 4.

Ketuntasan belajar siswa pada siklus I

\begin{tabular}{cccc}
\hline $\begin{array}{c}\text { Jumlah } \\
\text { siswa }\end{array}$ & $\begin{array}{c}\text { Belum } \\
\text { tuntas }\end{array}$ & Tuntas & $\begin{array}{c}\text { Persentase } \\
\text { ketuntasan }\end{array}$ \\
\hline 30 & 11 & 19 & $63,33 \%$ \\
\hline
\end{tabular}

Ketuntasan belajar pada siklus

I telah mencapai $63,33 \%$, berarti telah memenuhi indikator kinerja penelitian yaitu $60 \%$ siswa memperoleh nilai hasil belajar $\geq 61$ pada siklus I.

\section{Refleksi Tindakan Siklus I}

Pada siklus I telah dilaksanakan pembelajaran dengan menggunakan pendekatan pembelajaran berbasis TIK pada materi refleksi, yaitu "Refleksi terhadap sumbu-X, Refleksi terhadap sumbu-Y, Refleksi terhadap titik pangkal $\mathrm{O}(0, \quad 0))$ ”. Proses pembelajaran berlangsung cukup kondusif, siswa sudah mulai menunjukkan aktivitas belajar yang cukup baik, lebih terarah, sebagian besar siswa sudah terotivasi untuk mengikuti proses pembelajaran.

Aktivitas yang timbul dari siswa akan mengakibatkan pula terbentuknya pengetahuan dan keterampilan yang akan mengarah pada peningkatan kemamapuan pamahaman konsep yang diinginkan, dengan paham terhadap konsep yang diinginkan maka secara langsung berdampak pada peningkatan hasil belajar yang lebih baik. Hal ini bisa dilihat dari hasil tes siswa mengalami peningkatan dibandingkan dengan kondisi awal. Jika dibandingkan dengan kondisi awal, nilai terendah naik 30\% dari 25 menjadi 32,5. Nilai tertinggi naik $12,5 \%$ dari 80 menjadi 90. Rata-rata nilai naik 47,37\% dari 44,67 menjadi 65,83.

Persentase jumlah siswa yang telah tuntas belajar juga meningkat. Ketuntasan belajar siswa pada siklus I telah mencapai 63,33\%, berarti telah memenuhi indikator kinerja penelitian yaitu $60 \%$ siswa memperoleh nilai hasil belajar $\geq 61$ pada siklus I.

Adapun kekurangankekurangan pada siklus satu sesuai hasil lembar observasi aktivitas siswa dan lembar observasi yang diperoleh merupakan catatan untuk dilakukan perbaikan pada saat pelaksanaan tindakan pada siklus dua.

\section{Deskripsi Hasil Siklus II}

Pada siklus II ini ada tiga kali pertemuan. Pada pertemuan pertama direncanakan pembelajaran dengan materi "menemukan konsep rotasi (perputaran)", pertemuan kedua direncanakan pembelajaran dengan materi "dilatasi (perkalian bangun)". Pada pertemuan ketiga kemudian melakukan post-test siklus II.

\section{Aktivitas Siswa pada siklus II.}

Berikut adalah gambaran hasil observasi yang telah dilakukan oleh observer selama proses pembelajaran pada siklus II setelah diadakannya perbaikan berdasarkan tahap refleksi pada siklus I: 1) Motivasi belajar sudah terlihat semakin meningkat, siswa antusias untuk bertanya jika masih ada materi yang belum jelas; 2) siswa termotivasi supaya bisa 
mendapatkan peningkatan skor individu yang akan berpengaruh pada nilai kelompok mereka; 3) Siswa tampak aktif berdiskusi untuk merekonstruksi pengetahuan melalui berdiskusi, sudah berani bertanya jika ada hal yang mereka anggap kurang jelas, ketika peneliti memberi penguatan dengan melibatkan siswa, siswa sudah berani mengajukan pendapat walaupun pendapat yang diberikan belum terlalu sempurna dalam hal kalimat yang diucapkan, namun peneliti tetap memberikan penghargaan berupa pujian, sementara siswa lain disuruh untuk melengkapi dengan pernyataan atau kalimat yang benar; 4) LKPD yang sudah didiskusikan secara kelompok bisa dipresentasikan dengan lebih optimal dari sebelumya.

\section{Hasil Tes Kemampuan Pemahaman Konsep}

Dari hasil tes siklus II yang telah dilakukan, terdapat 25 siswa dari 30 siswa yang kemampuan pemahaman konsepnya memperoleh kriteria baik. Hal ini telah memenuhi indikator keberhasilan yang diinginkan. Hasil belajar siswa mengalami peningkatan dari siklus 1 . Nilai terendah naik $61,5 \%$ dari 32,5 menjadi 52,5. Nilai tertinggi naik 5,56\% dari 90 menjadi 95. Rata-rata nilai naik $17,36 \%$ dari 65,83 menjadi 77,42. Persentase jumlah siswa yang telah tuntas belajar juga meningkat. Ketuntasan belajar siswa pada siklus I adalah:

Tabel 5.

Ketuntasan belajar siswa pada siklus II

\begin{tabular}{cccc}
\hline $\begin{array}{c}\text { Jumlah } \\
\text { siswa }\end{array}$ & $\begin{array}{c}\text { Belum } \\
\text { tuntas }\end{array}$ & Tuntas & $\begin{array}{c}\text { Persentase } \\
\text { ketuntasan }\end{array}$ \\
\hline 30 & 5 & 25 & $83,33 \%$ \\
\hline
\end{tabular}

Ketuntasan belajar pada siklus II telah mencapai $83,33 \%$, berarti telah memenuhi kriteria dikatakan tuntas dalam mengikuti pembelajaran jika nilainya $\geq 70$. Sedangkan secara klasikal, suatu kelas dianggap tuntas bila $75 \%$ siswa dikelas memperoleh $\geq 70$.

\section{Refleksi Tindakan Siklus II}

Berdasarkan
tindakan siklus II $\begin{array}{r}\text { meliputi } \\ \text { perencanaan dan pelaksanaan }\end{array}$ tindakan serta hasil observasi yang dilakukan, dapat dilakukan hasil refleksi. Dari hasil observasi siklus II dapat dikatakan bahwa proses pembelajaran sudah menunjukan hasil yang optimal. Berdasarkan hasil analisis pemahaman konsep siswa terhadap tes siklus II diketahui nilai rata-rata pemahaman konsep siswa sebesar 77,42 dan berdasarkan pedoman kualifikasi hasil tes yang telah ditentukan, persentase tersebut termasuk dalam kategori tinggi. Rata-rata nilai pemahaman konsep siswa tersebut meningkat dari siklus I yang diketahui sebesar 65,83 .

Tindakan pada siklus II yang sudah diperbaiki berdasarkan hasil refleksi dari siklus I menunjukkan rata-rata pemahaman konsep siswa mengalami peningkatan. Hal ini disebababkan siswa mulai terbiasa dengan proses pembelajaran yang dirancang oleh peneliti secara terorganisir dari awal pembelajaran/tahap pendahuluan sampai penutupan, diawal pembelajaran siswa terlihat antusias untuk mengikuti proses pembelajaran, ketika proses pembelajaran berlangsung siswa terlihat aktif untuk bertanya jika masih ada materi yang belum jelas, 
siswa termotivasi supaya bisa mendapatkan peningkatan skor individu yang nantinya akan berpengaruh pada nilai kelompok mereka.

Proses pembelajar yang dilakukan secara kelompok pada siklus II sudah berjalan jauh lebih baik dari siklus I. Siswa yang tadinya hanya menyalin jawaban teman, sudah ikut terlibat dalam diskusi kelompok.

Siswa tampak aktif berdiskusi untuk merekonstruksi pengetahuan melalui berdiskusi, sudah berani bertanya jika ada hal yang mereka anggap kurang jelas, ketika peneliti memberi penguatan dengan melibatkan siswa, siswa sudah berani mengajukan pendapat, dan juga berani mempresentasikan hasil diskusi kelompok. Dengan rangkaian aktivitas yang diikuti oleh siswa dalam proses pembelajaran dengan antusias, motivasi yang tinggi menyebabkan siswa dapat memahami konsep yang diajarkan, hal ini merupakan penyebab mengapa rata-rata pemahaman konsep siswa mengalami peningkatan.

Rata-rata pemahaman konsep siswa mengalami peningkatan dalam kategori tinggi sehingga dapat disimpulkan bahwa penerapan model pembelajaran berbasis TIK menggunakan Aplikasi software geometer's sketchpad dapat meningkatkan rata-rata persentase pemahaman konsep siswa pada materi transformasi, sehingga indikator keberhasilan yang telah ditetapkan pada siklus II terpenuhi maka tindakan sudah dapat dihentikan.

\section{Data Hasil Pelaksanaan PTK \\ Data Hasil Observasi Aktivitas Siswa dalam Proses Pembelajaran}

Observasi dilakukan untuk mengetahui aktivitas siswa dalam proses pembelajaran matematika dengan penerapan model pembelajaran menggunakan software geometer's sketchpad mulai dari refleksi awal sampai akhir siklus II.

Hasil observasi menunjukkan bahwa pada refleksi awal persentasi aktivitas siswa dalam proses pembelajaran berada pada katagori sangat kurang. Pada siklus I aktivitas siswa dalam proses pembelajaran mengalami peningkatan bisa dikatakan berada pada katagori cukup baik. Pada siklus II, aktivitas siswa dalam mengikuti proses pembelajaran meningkat serta dapat digolongkan dalam kategori tinggi, dapat dilihat dari hasil pengamatan baik pengamatan peneliti maupun pengamatan teman sejawat, semua siswa sudah terlibat aktif atau tidak ada lagi siswa yang tidak terlibat aktif dalam mengikuti proses pembelajaran dengan menggunakan menggunakan software geometer's sketchpad.

\section{Data Hasil Tes}

Tes ini diberikan pada setiap akhir siklus dan dimaksudkan untuk mengetahui peningkatan pemahaman konsep siswa. Secara keseluruhan, berdasarkan analisis hasil tes pada saat refleksi awal, tes siklus I, dan tes siklus II dengan penerapan model pembelajaran berbasis TIK mengalami peningkatan. Hal tersebut bisa dilihat dari tabel pemahaman konsep siswa berikut ini. 
Tabel 6.

Persentase pemahaman konsep siswa terhadap tes siklus

\begin{tabular}{|c|c|c|c|c|}
\hline no & $\begin{array}{c}\text { aspek } \\
\text { pemahaman } \\
\text { konsep }\end{array}$ & $\begin{array}{c}\text { pra } \\
\text { siklus }\end{array}$ & siklus i & $\begin{array}{c}\text { siklus } \\
\text { ii }\end{array}$ \\
\hline 1 & $\begin{array}{l}\text { menyatakan } \\
\text { ulang sebuah } \\
\text { konsep secara } \\
\text { verbal atau } \\
\text { tulisan. }\end{array}$ & $81,67 \%$ & $84,33 \%$ & $91,67 \%$ \\
\hline 2 & $\begin{array}{l}\text { dapat memilih, } \\
\text { membedakan } \\
\text { antara contoh- } \\
\text { contoh dan } \\
\text { yang bukan } \\
\text { contoh. }\end{array}$ & $61,67 \%$ & $82,78 \%$ & $90,56 \%$ \\
\hline 3 & $\begin{array}{l}\text { menyajikan } \\
\text { konsep dalam } \\
\text { berbagai } \\
\text { bentuk } \\
\text { representasi } \\
\text { matematis. }\end{array}$ & $27,92 \%$ & $54,17 \%$ & $66,67 \%$ \\
\hline 4 & $\begin{array}{l}\text { mengaplikasik } \\
\text { an konsep atau } \\
\text { algoritma } \\
\text { kedalam } \\
\text { pemecahan } \\
\text { masalah }\end{array}$ & $33,33 \%$ & $53.75 \%$ & $84,17 \%$ \\
\hline & rata-rata & $51,15 \%$ & $68,76 \%$ & $83,27 \%$ \\
\hline & kategori & rendah & sedang & tinggi \\
\hline
\end{tabular}

Dari tabel tersebut dapat
diketahui kemampuan pemahaman konsep siswa pada setiap siklus mengalami peningkatan dan tergolong dalam kategori tinggi.

Gambar berikut adalah grafik persentase pemahaman konsep siswa dari kondisi awal (prasiklus), siklus I dan siklus II dilihat dari empat aspek pemahaman konsep yang disajikan dalam diagram batang.

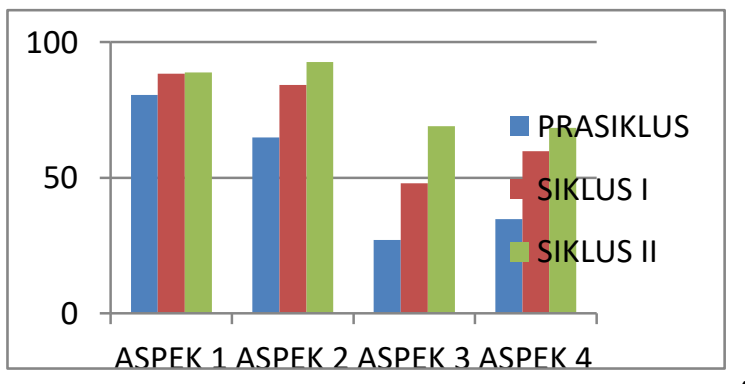

Gambar 1. Grafik persentase pencapaian aspek pemahaman konsep matematika

Aspek pemahaman konsep memuat beberapa poin yaitu; 1) menyatakan ulang sebuah konsep secara verbal atau tulisan, 2) dapat memilih, membedakan antara contoh-contoh dan yang bukan contoh, 3) Menyajikan konsep dalam berbagai bentuk representasi matematis, 4) mengaplikasikan konsep atau algoritma kedalam pemecahan masalah.

Berdasarkan grafik persentase aspek pemahaman konsep siswa pada gambar tersebut, uraian pemahaman konsep siswa dilihat dari persentase pencapaian per aspeknya yaitu;

1. menyatakan ulang sebuah konsep secara verbal atau tulisan. Pada pra siklus persentase rata-rata pencapaian siswa dalam menyatakan ulang sebuah konsep secara verbal atau tulisan sebesar $81,67 \%$ dan mengalami peningkatan $84,33 \%$ pada siklus I dan $91,67 \%$ pada siklus II.

2. Dapat memilih, membedakan antara contoh-contoh dan yang bukan contoh. Pada pra-siklus persentase rata-rata pencapaian siswa dalam memilih, membedakan antara contohcontoh dan yang bukan contoh sebesar $61,67 \%$ dan mengalami peningkatan pada siklus I dan siklus II yaitu menjadi $82,78 \%$ dan $90,56 \%$,

3. Menyajikan konsep dalam berbagai bentuk representasi matematis. Pada pra siklus persentase rata-rata pencapaian siswa pada aspek ketiga yaitu 
menyajikan konsep dalam berbagai bentuk representasi matematis sebesar $27,92 \%$ dan mengalami peningkatan pada siklus I menjadi $54,17 \%$ dan pada siklus II mengalami peningkatan $66,67 \%$.

4. Mengaplikasikan konsep atau algoritma kedalam pemecahan masalah. Pada pra siklus persentase rata-rata pencapaian

Tabel 7.

Hasil Penelitian Pra Siklus, Siklus I, dan Sikus II siswa dalam mengaplikasikan konsep atau algoritma kedalam pemecahan masalah hanya sebesar 51,15\%, pada tes siklus I mengalami peningkatan sebesar $68,76 \%$, dan peningkatan siklus II yaitu menjadi $83,27 \%$, Secara rinci hasil penelitian disajikan dalam tabel berikut.

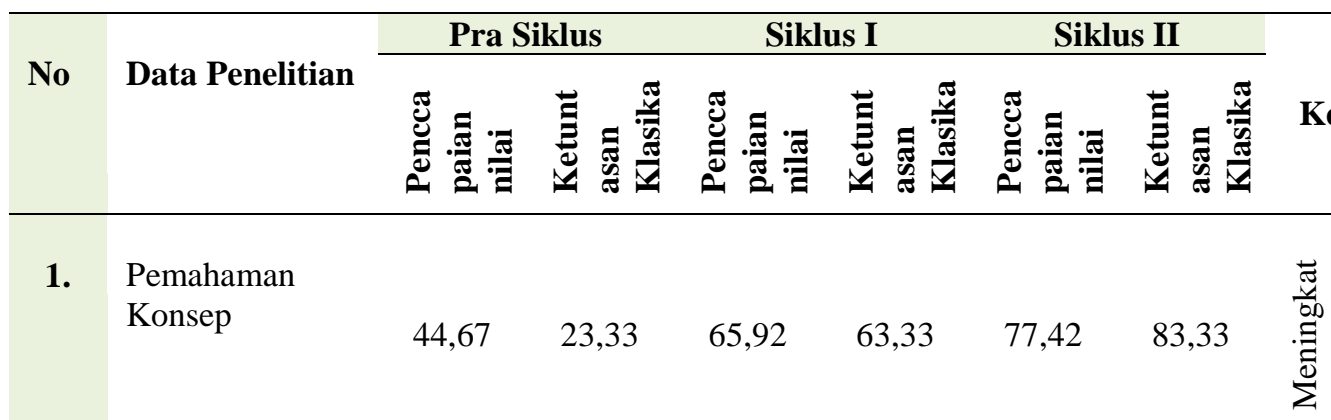

\begin{tabular}{|c|c|}
\hline Kategori & Kurang \\
\hline PEMBAHASAN & \\
\hline $\begin{array}{l}\text { Pembahasan Tiap } \\
\text { Antar Siklus }\end{array}$ & Siklus \\
\hline
\end{tabular}

Keterlaksanaan pembelajaran matematika dengan penerapan model pembelajaran berbasis TIK menggunakan software geometer's sketchpad sesuai tahapan-tahapan pada pedoman observasi yang sudah disusun peneliti sebelumnya. Pada siklus I, penerapan model pembelajaran berbasis TIK menggunakan software geometer's sketchpad masih belum bisa meningkatkan pemahaman konsep secara maksimal.

Masih ada satu aspek tergolong dalam kategori rendah, yaitu aspek ketiga dan keempat yaitu tentang menyajikan konsep dalam bentuk representasi matematis dan

Sedang
mengaplikasikan konsep atau
algoritma dalam pemecahan
masalah, dimana rata-rata
pencapaiannya berturut-turut hanya
$54,17 \%$ dan 53,75\%. Hal ini
disebabkan oleh tingkat kesulitan
soal yang tergolong lebih tinggi
dibanding dengan aspek yang lain,
dan interaksi siswa saat proses
pembelajaran pada siklus I belum
optimal.

Interaksi antar siswa berpengaruh pada kemampuan mengaplikasikan konsep atau algoritma dalam pemecahan masalah. karena interaksi antar siswa tersebut membuat siswa melakukan proses sosial seperti saling berpendapat serta saling menjelaskan dalam mengkonstruksi konsep yang menjadi tujuan pembelajaran sehingga konsep tersebut akan 
bermakna bagi siswa. Jika siswa memaknai konsep tersebut maka siswa akan cenderung lebih mudah dalam mengaplikasikan konsep atau algoritma dalam pemecahan masalah.

Hal ini sejalan dengan teori Burton dalam sebuah buku "The Guideance of Learning Avtivities" (Rikianto Baeng, 2013) belajar sebagai perubahan tingkah laku pada diri individu berkat adanya interaksi antara individu dengan individu dan individu dengan lingkungannya sehingga mereka mampu berinteraksi dengan lingkungannya.

Aktivitas yang timbul dari siswa akan mengakibatkan pula terbentuknya pengetahuan dan keterampilan yang akan mengarah pada peningkatan pemahaman konsep yang diharapkan, yang berakibat pada peningkatan hasil belajar yang lebih baik. Hal ini sejalan dengan pernyataan Sudjana (1989) yang menyatakan bahwa belajar adalah suatu proses yang ditandai dengan adanya perubahan pada diri seseorang. Perubahan hasil proses belajar dapat ditunjukkan dalam berbagai bentuk seperti penambahan pengetahuan, pemahaman, sikap dan tingkah laku, kecakapan, kebiasaan serta perubahan aspek-aspek lain yang ada pada individu-individu yang belajar.

Sedangkan pada siklus II, semua aspek berhasil mengalami peningkatan, berturut-turut dari aspek kesatu yaitu 91,67\%, aspek kedua 90,56\%, aspek ketiga 66,67 dan aspek keempat $84,17 \%$, pada siklus ke II siswa sudah lebih terarah untuk dapat memahami konsep yang diajarkan dengan aktif terlibat dalam proses pembelajaran, hingga siswa merasa mengalami sendiri melalui pengamatan langsung dari impormasi yang peneliti tayangkan melalui power poin maupun langsung mengamati benda nyata serta melakukan percobaanpercobaan langsung.

Hal ini sejalan dengan pernyataan Higgins (dalam Mardiah, 2012) menyatakan bahwa siswa akan lebih bisa memahami dan memaknai konsep yang menjadi tujuan pembelajaran jika siswa terlibat aktif dalam pembelajaran yang berlangsung. Selain itu suatu konsep akan lebih dipahami dan diingat oleh siswa apabila konsep tersebut disajikan melalui prosedur atau langkah-langkah yang menarik, Hal ini sejalan dengan teori Bruner "dalam proses belajar anak baiknya diberi kesempatan memanipulasi benda-benda atau alat peraga yang dirancang secara khusus dan dapat diotak-atik oleh siswa dalam memahami suatu konsep matematika.

Melalui alat peraga yang ditelitinya siswa dapat melihat langsung bagaimana keteraturan dan pola struktur yang terdapat dalam benda yang diperhatikannya," sehingga proses pembelajaran yang langsung dialami oleh siswa terasa lebih bermakna dan dapat menemukan konsep melalui aktivitas yang mereka lihat sendiri, dan lakukan sendiri, sehingga siswa benar-benar dapat meningkatkan pemahaman konsep, serta dampaknya hasil belajarpun lebih meningkat.

Pada siklus II, kegiatan belajar kelompok berjalan lebih baik, semua siswa sudah terlihat aktif dan terbiasa dengan teman 
sekelompoknya, dalam kerja kelompok diberikan tanggung jawab individu yang berdampak pada penilaian kelompok, hingga semua kelompok berlomba untuk mendapat nilai terbaik, dalam hal ini jika ada teman sekelompoknya yang belum mengerti, otomatis siswa yang berkemampuan tinggi dalam kelompok memberikan bantuan, hal ini berdampak siswa yang berkemampuan tinggi akan semakin berkembang kemampuannya dan dapat diberdayakan untuk menjadi tutor sebaya bagi teman kelompoknya yang berkemampuan kurang, sehingga siswa yang berkemampuan rendah akan meningkat menjadi lebih baik, ditinjau dari aktivitasnya dalam mengikuti proses pembelajaran yang otomatis berdampak pada peningkatan pemahaman konsepnya. Menurut Slavin (2008), tujuan pembelajaran kooperatif adalah menciptakan situasi dimana keberhasilan individu ditentukan atau dipengaruhi oleh keberhasilan kelompoknya.

\section{SIMPULAN}

Pembelajaran dengan menggunakan software geometer's sketchpad dapat meningkatan kemampuan pemahaman konsep materi Transformasi pada siswa kelas IX SMP negeri 1 Tebat Karai Kabupaten Kepahiang.

Penerapan pembelajaran berbasis TIK dengan menggunakan software geometer's sketchpad tersebut dapat meningkatkan aktivitas siswa kelas VII.B SMPN 1 Tebat Karai pada materi transformasi (refleksi, translasi, rotasi, dilatasi). Peningkatan tersebut ditunjukkan dari hasil pengamatan peneliti sendiri yang dibantu oleh teman sejawat.

\section{DAFTAR PUSTAKA}

Arsyad, A. (2002). Media pembelajaran. Jakarta: Raja Grafindo Persada.

Lam, T., T. (2007). Use of Geometer's Sketchpad (GSP) to Teach Mechanics Concepts in $A$ Level Mathematics. [Online].

Tersedia:http://www.any2any.or g/EPATCM/EP/2004/2004C141/f ull paper.pdf.

Mardiah. (2012). Meningkatkan Kemampuan Pemahaman Konsep dan Aktivitas Siswa Melalui Pembelajaran Kooperatif Model Student Teams-Achievement Divisions untuk di Kelas VIII SMP 3 Muara Keтити.

Nugraha, D., A. (2017). Penerapan Pembelajaran Berbasis Masalah Berbantuan Program Geometer's Sketchpad untuk Meningkatkan Kemampuan Representasi Multipel Matematis Siswa. Jurnal Teori dan Riset Matematika (TEOREMA) 1(2); 1-10.

Rikianto, B. (2013). Teori Belajar dan Pembelajaran [online].(http://rikiantobaeng.bl ogspot.com/2013/06/teoribelajar-teoripembelajaranhtml). Diakses pada tanggal 03 Maret 2014.

Saleh, H. (2014). Meningkatkan Kemampuan Pemahaman Konsep Melalui Pembelajaran Matematika CONSEPTRICHI. Prosiding Seminar 
2019. Jurnal Pendidikan Matematika : Judika Education 2(1); 36-49

Nasional Pendidikan

Matematika UNIB 2014.

Slavin \& Robert, E. (2008).

Cooperative Learning Teori

Riset dan Praktik. Bandung:

Nusa Media. 